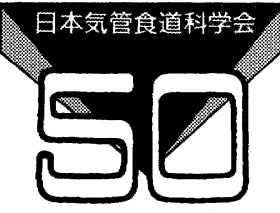

記念講演

\title{
喉頭麻痺の病態生理一特に声帯位について
}

\author{
廣戸幾一郎，藤沢成人，小宮山荘太郎*
}

\section{Vocal Fold Mobility and Position in Laryngeal Paralysis}

Ikuichiro Hiroto, M.D., Shigeto Fujisawa, M.D., and Sohtaro Komiyama, M.D.

Department of Otolaryngology, Kyushu University School of Medicine, Fukuoka, ret.

Twenty four cases of unilateral laryngeal paralysis were examined by contrast laryngography. The characteristic feature of the laryngeal paralysis in these contrast laryngogram was that the vocal fold on the affected side was fixed in the half adducted position during respiration. This corresponded to the laryngoscopic view of the vocal fold fixed at the intermediate position. During phonation, the larynx was seen to be elevated, and the shape of the laryngeal cavity changed. However, the tracheal portion of the vocal tract did not change on the contrast laryngogram. When the contrast laryngograms taken during respiration and phonation were superimposed at the unchanging tracheal portion, the movement of the vocal folds could be measured and quantified. The vocal fold on the affected side was slightly adducted during phonation in 10 out of the 24 cases of unilateral paralysis, and abducted in 2 cases (paradoxical movement due to misdirected regeneration of the recurrent laryngeal nerve) and fixed in the rest 12 cases. The position of the vocal fold on the affected side during phonation was related to its mobility. When it was slightly adducted, it seemed to be fixed at the paramedian position in the laryngoscopic examination. When it was not adducted, it was fixed at the intermediate position.

\section{Key words : 喉頭麻痺, 喉頭造影法, 声帯可動性, 声帯位}

\section{I 、はじめに}

喉頭麻痺, いわゆる反回神経麻痺における喉 頭鏡像には，麻痺側声帯が中間位に固定して動 かないものと, 副正中位, あるいは正中位に固 定して動かないものとの，2 型があることは常 識となっている。同一疾患であるのに，何故こ のように声帯の位置に差があるのか。このこと を説明するために, Semon 学説とWagner, Grossmann 学説とが唱えられており, 数十年間

元九州大学医学部耳鼻咽喉科学教室, ${ }^{*}$ 九州大学医学 部耳鼻咽喉科学教室

別刷請求： $\bar{\top} 810-0045$ 福岡市中央区草香江1-2-13 廣戸幾一郎
にわたって世界の咽喉科医の頭を支配してきた ことは周知のことであるが，1968年，私どもの 筋電図学的研究によって両説とも否定されたこ とも，ご承知の通りである。その後，これらの 説に代わるべき学説は提示されておらない。 喉頭麻痺に関する従来の研究は, ほとんどす べてが，何故声帯が中間部に固定されたり，副 正中位に固定されたりするのかという問題，す なわち麻痺側声帯の位置の問題に関するものば かりで, 声帯が動かないということそのものに 関しては，何の疑いも持たれずにきた。

筋電図学的研究によると年3), 喉頭麻痺が発生 してから 1 年もたつと, 麻盘側声帯には全く筋 電図が認められないか，あるいは弱いけれども 
正常筋電図が認められるかの, いずれかになる ということがわかっている。筋電図が認められ ない場合には, 筋は全く麻痺しているのである から, 声帯が動かないことの説明は容易である。 しかし, 筋電図が認められる場合には, なぜ声 帯が動かないかの説明は容易ではない。声帯が 動かないのは, 反回神経の神経繊維の過誤再生 に基づく, 内転筋と外転筋という拮抗筋の同時 収縮によるためだと, 一応は考えられてき た ${ }^{4,5)}$ 。しかし，たとえ過誤再生があるとはいえ， 実際に筋肉は収縮しているのであるから, 声帯 が動かないことの説明には納得し難いものがあ る。声帯が同じように不動にみえても, 両者の 間には, 何らかの差があって当然である。声帯 が喉頭鏡下に不動にみえるだけであって, 実際 は少しは動いているのではなかろうか。こうい った疑問は起こらざるをえない。

\section{II ．間接喉頭鏡像による検討}

間接喉頭鏡像を客観的に観察するため, 間接 喉頭鏡を用いて撮影した喉頭麻痺症例の普通速 度映画 ${ }^{6)}$ について, 解析を試みた。呼吸時と発声 時の一コマずつを抽出して, 拡大焼き付けし, その各々をトレーシングペーパーにトレース し, トレースされたコマを重ね合わせて, 麻痺 側声帯が動いているか否かを検討した。図 1 は, 左が中間位固定, 右が副正中位固定とみなされ た例であり, 点線は呼吸時の声帯像を, 実線は 発声時の声帯像を示している。発声時には, 喉 頭は全体として右側に移動しており, 呼吸時と 発声時の喉頭鏡像はずれていて, 麻痺側声帯が 不動であるか, 可動であるかを判定することは 不可能であった7)。

このことは, 喉頭は発声時には挙上されるか ら，喉頭鏡が斜めに把持されているためにずれ て映るのだと考えられる。従来, 麻痺側声帯が 不動であると信じられてきたのは, 間接喉頭鏡 所見に基づくものであるから, 映画による解析 という新しい検討方法を用いても，この問題を 解決することができないのは当然であろう。

\section{III. 喉頭造影像における喉頭麻盘の特徵}

上からみてダメなら，横からみて検討しよう と, 喉頭造影像による検討を試みた。
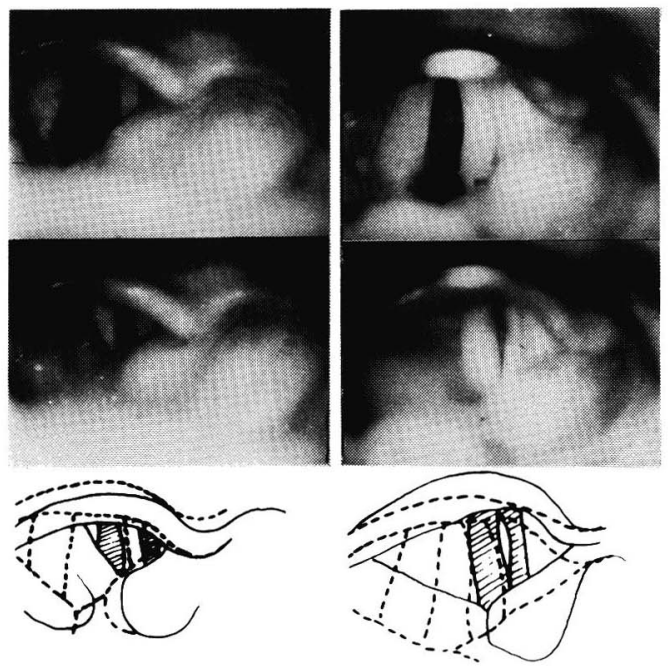

図 1 間接喉頭鏡映画による喉頭麻痺の声帯像の解析
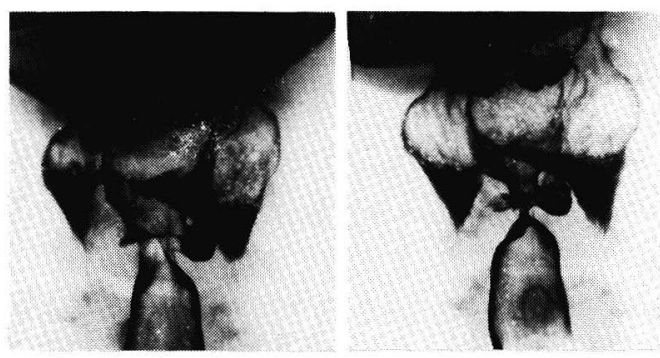

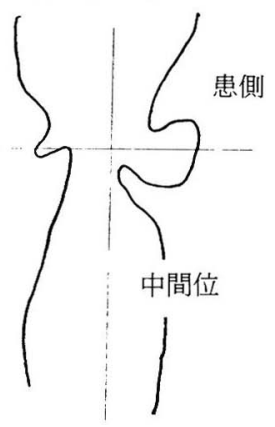

呼吸時

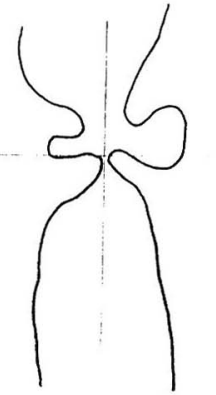

発声時
図2 喉頭造影法における喉頭麻痺の声帯像の特徵

喉頭麻痺の喉頭造影像の特徵は年, 図 2 に示 すごとく，一般には，1）麻痺側声帯は内下方 に変位し, 声帯はうすくなり, 先端は舌状に尖 つて上を向く。呼吸時も発声時も, その位置と 形がほとんど変わらない。2 ) 麻痺側喉頭室は 拡大し, その広さは呼吸時も発声時もほとんど 変わらない。3）呼吸時には喉頭室の左右非対 
称が目立つが，発声時には声帯下面の非対称が 印象的である。4 ) 梨状陥凹は麻痺側が拡大さ れているが, 発声時には健側とほぼ同大となる, とされている。

声帯位の検討には，上述の 4 項目のうち 1) が重要であって, 後述する喉頭造影像重ね合わ せ法では, 呼吸時と発声時の麻痺側声帯の位置 と形は同じ場合もあれば，変化する場合もある から，正確には次のごとく記述しなければいけ ない。

喉頭麻痺の喉頭造影像の特徵は,「呼吸時」の 造影像で, 麻痺側声帯が半ば内転状態で突出し てみえることである。

これは, 喉頭鏡像にあてはめると, 麻痺側声 帯が中間位にあることを示すものであって，発 声時に声帯が副正中位に固定されてみえる例で も，中間位に固定されてみえる例でも皆同じで ある。すなわち, 喉頭麻痺の麻痺側声帯は, 「呼 吸時」には全例が中間位にあるということであ る。

ところで，喉頭鏡による声帯位の診断は，発 声時になされるのが通例である。発声時には健 側声帯は正中位まで内転するから，健側の声帯 縁を基準とすれば，患側声帯の位置の確認が容 易だからである。これは, 喉頭麻痺の麻痺側声 帯は呼吸時も発声時も全く不動であるという, 誤った前提にたっての判断なのである。

したがって, 呼吸時の喉頭造影像では声帯は 中間位にあるのに, 発声時の喉頭鏡像では副正 中位にあったり，中間位にあったりするという ことになるのである。

\section{IV．喉頭造影像重ね合わせ法による検討}

声帯が動くか動かないかを検討するために， 喉頭造影像重ね合わせ法という研究方法を創案

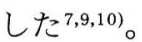

\section{1. 方法}

発声時には喉頭は挙上され, 声帯は内転する。 喉頭内腔の位置と形は発声時には変化するとい うことである。しかし，輪状軟骨より下方の気 管の形は，たとえ気管が発声時に，喉頭の挙上 に伴って引き上げられても, その形はほとんど 変化しない。したがって, 呼吸時と発声時に喉 頭造影像を撮影し，気管を含めてトレーシング

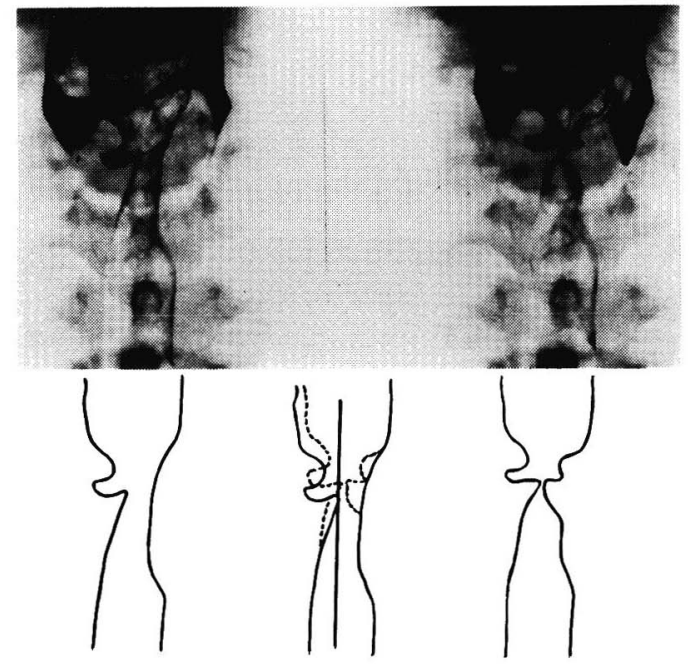

図 3 喉頭造影像重ね合わせ法

ペーパーにトレースし，両者を気管部分で正確 に重社合わせると，喉頭内腔の形状の変化を量 的に比較計測することができる。二重撮影法に 類するものである。

正常者 2 名について, 足と軀幹の位置はその ままとし，頭部を前後左右に屈曲あるいは回旋 した後，真ん前を向かせて停止させ，喉頭造影 像を撮影する。この動作を 5 回繰り返し, 各 5 枚の影像を比較検討してみたが，左右方向のズ レは $1 \mathrm{~mm}$ 以内，上下方向のズレは $2 \mathrm{~mm}$ 以内 であったから，頭を動かさないように指示して 撮影した呼吸時, 発声時の喉頭造影像について, 喉頭各部位の動きを量的に計測する場合の誤差 はほとんど無視しても差し支えないと考えられ る。

喉頭造影像重ね合わせ法の一例を示すと, 図 3 のごとくである。この例は右側喉頭麻痺症例 で, 上段は左が呼吸時, 右が発声時の喉頭造影 像, 左下は呼吸時のトレース像, 右下は発声時 のトレース像，両方のトレース像を重ね合わせ ると中下のようになる。実際には，呼吸時の麻 痺側の声帯縁に接して, 気管の垂直軸に平行な 垂直線を描き，この線から発声時の声帯縁まで の距離を測定した。図 3 の例では, 健側声帯は $4 \mathrm{~mm}$ 内転し, 患側声帯はほとんど内転してい ない。 


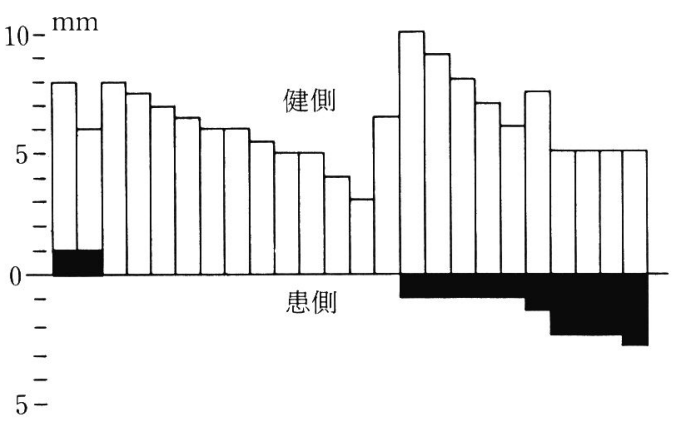

図4 喉頭造影像重ね合わせ法による喉頭麻痺声帯 の内転距離

表 1 喉頭造影像重ね合わせ法による喉頭麻痺声带 の内転距離

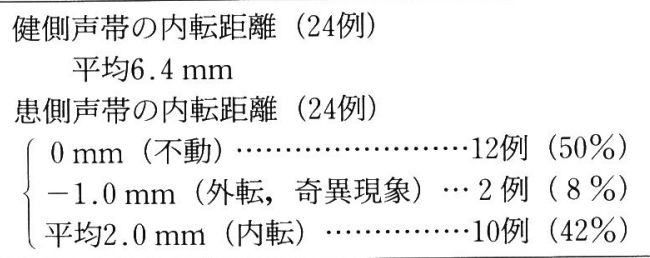

\section{2. 成績}

この喉頭造影像重ね合わせ法を，片側喉頭麻 痺24例に施行した。

図 4 はその成績である。健側声帯の内転距離 は白棒で, 麻痺側声帯の内転距離は黒棒で示さ れている。図の左端，2例の黒棒が逆に向いて いるのは, 神経の過誤再生に基づく奇異現象と 思われるもので, 発声時に麻痺側声帯が内転で はなく，外転していることを示している。棒が ないものは，声帯が不動であることを示すもの である。以上の成績をまとめると，表 1 のごと くである。

1）24例中，麻痺側声帯が全く不動のものは 12例 $(50 \%)$ である。それ故，奇異現象の 2 例 を含めて，14例において，発声時に声門は開大 したままである。喉頭鏡検査では，これらの例 では患側声帯は中間位に固定されてみえるであ ろう。

2 ）しかし, 患側声带は24例中10例, 半数弱 において，内転運動をしている。決して不動で はないのである。そして声門はほとんど閉鎖し てみえる。これらの例では，喉頭鏡検査では，

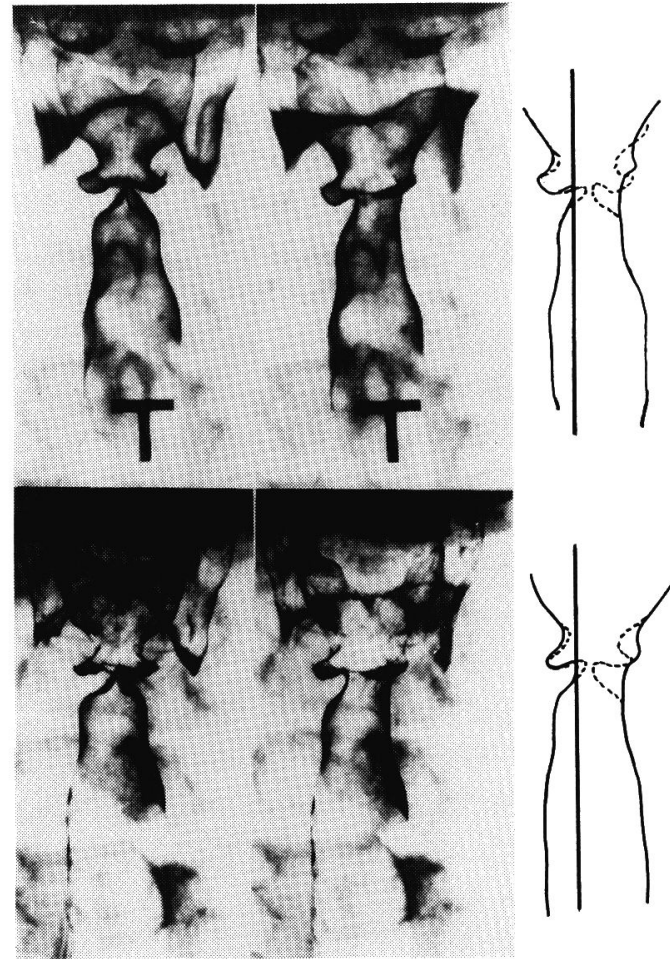

図 5 時期を異にして 2 回喉頭造影法が施行された例

患側声帯は副正中位に固定されてみえるであろ う。

3 ) 健側声帯の内転距離は, 平均 $6 \mathrm{~mm}$ 強 ( $3 \sim 10 \mathrm{~mm}$ ) であるが，患側声帯の内転距離は その半分以下, 平均 $2 \mathrm{~mm}(1 \sim 3 \mathrm{~mm})$ に過ぎ ない。発声時に, 健側声帯は呼吸時の位置, す なわち側位 lateral position より正中位まで内 転するが，その距離が $6 \mathrm{~mm}$ ということであ る。患側声帯の内転距離が $2 \mathrm{~mm}$ であるという ことは，中間位より副正中位までの内転である ことを示している。

ここで，診断的示唆に富んだ症例を提示した い。図 5 に示す例である。この例は右喉頭麻痺 の症例で，時を異にして 2 回，喉頭造影法が施 行されている。しかもどちらの時も，喉頭鏡下 では右声帯は不動であると診断されている。図 5 の上の図は発症後 2 力月目, 下の図は発症後 7 力月目のものである。 2 力月目も 7 力月目も 同じ成績であって, 健側声帯は $5 \mathrm{~mm}$ 内転し, 患側声帯は $2 \mathrm{~mm}$ 内転している。健側声帯の内 転距離の約半分も内転しているのであるから, 
また 2 回も検査しているのであるから, 患側声 帯の可動性に気づきそうなものであるが，2力 月目も 7 カ月目も喉頭鏡による診断は同じであ って，右反回神経麻痺となっていた。この理由 は三つ考えられる。

1）医師が，喉頭麻痺における麻痺側声帯は 全く動かないものと初めから思い込んでおり， 少しの動きには注意を払わなかったこと，

2 ）喉頭鏡の傾斜のために，喉頭が全体とし てどちらかの側にずれて動き，確認し難いだけ でなく，

3 ）健側声帯の大きい運動に眼を奪われ，麻 痺側声帯の小さな運動は眼にとまらず，患側声 帯が固定しているかのようにみえたこと。

この三つのためと思われる。

以上のことょり，患側声帯が可動性の場合に は, すなわち呼吸時の中間位から発声時の副正 中位まで内転する場合は, 小さな運動のために 注意をひかず，声帯は副正中位に固定している かのようにみえるのである。

また，患側声帯が不動で内転しない場合は, 声帯は中間位に固定したままであるのである。

言い換えると, 患側声帯が中間位に固定して みえる時は，実際に中間位に固定しているので あるし, 副正中位に固定してみえる時は, 実際 は中間位から副正中位まで内転しているのであ る。

\section{V ．声帯位に影響するとの他の因子}

喉頭麻痺の麻痺側声帯の位置に，若干影響す る因子が他に二つある。

反回神経が麻痺すると, 内喉頭筋には不作動 性萎縮がおこる。筋肉は変性萎縮し, 最終的に は筋肉は消えて, 結合組織によって置換されて しまう。中間位固定の声帯で, 弓状に凹んでみ える場合は声帯筋が結合織化しているためであ る11 13)。

なお, 副正中位と正中位との差については， 麻痺側声帯の内転運動の大小の差によるものと 考えられるが, その他に声帯下面の粘膜の発声 時呼気流による「ずり上がり」の良否も多少は 関係するものと考えられる4)。

\section{VI. 結 論}

喉頭麻痺は患側声帯の可動性の有無によっ て, 完全麻痺型と不完全麻痺型とに分類するの がいいと思う。

1) 完全麻痺型では, 麻痺側声帯は中間位に 固定し, 全く不動で, 発声時に声門は開いたま まである。時に, 声带は萎縮して弓状を呈する。 恐らく筋電図は silent であろう。

2 ) 不完全麻痺型では, 麻痺側声帯は副正中 位あるいは正中位に固定してみえる。実際は中 間位から副正中位まで内転しているのである。 発声時に声門間隙はほとんど認められない。筋 電図は正常筋電図が認められるであろう。

\section{文献}

1 ) 富田英寿：反回神経麻㽻の筋電図学的研究. 日 耳鼻, $70 ： 963-985,1967$.

2) Hiroto, I., Hirano, M., and Tomita, H. : Electromyographic investigation of human vocal cord paralysis. Ann. Otol. Rhinol. Laryngol. (St. Louis), $77: 296-304,1968$.

3 ) Hiroto, I. : Evaluation of Laryngeal Function by Electromyography. Oto-RhinoLaryngology (Proceedings of the 9th International Congress), pp.320-323, 1970.

4 ) 廣戸幾一郎：発声機構の面よりみた喉頭の病態 生理. 耳鼻臨床, 39:229-291, 1966.

5 ) 廣戸幾一郎：反回神経麻痺. 臨床と研究, 44 : 2389-2394, 1967.

6 ) 廣戸幾一郎：反回神経麻愺 (映画). 日耳鼻, 71 : 621-622, 1968.

7 ）廣戸幾一郎, 武馬成人, 小宮山荘太郎・他：反 回神経麻痺における麻痺側声帯は果たして不動 か? 耳鼻, $21: 107-116,1975$.

8 ）廣戸幾一郎, 武馬成人, 小宮山荘太郎・他:喉頭 造影像 Laryngogram.耳鼻,18：446-449, 1972.

9 ）武馬成人：喉頭造影法による発声機構に関する 研究。耳鼻, $19: 789-819,1973$.

10）武馬成人, 廣戸幾一郎, 小宮山荘太郎・他：Laryngogram 重ね合わせ法による喉頭の機能診 断. 日気食会報, $24: 109-116,1974$.

11）飯塚俊勝：喉頭の神経支配，特に神経遮断と内 喉頭筋萎縮に関する実験. 日耳鼻, 69：177-195, 1966.

12）永嶋俊郎：反回神経麻痺に関する実験的研究, 特に内喉頭筋の変化について.耳鼻, 16(補 2)： 124-149, 1970.

13) Kirchner, J.A. : Atrophy of laryngeal muscles in vagal paralysis. Laryngoscope, $76: 1753^{-}$ $1765,1966$. 